\title{
Streptomyces vietnamensis sp. nov., a streptomycete with violet-blue diffusible pigment isolated from soil in Vietnam
}

Correspondence
Hong-hui Zhu
zhuhonghui66@yahoo.com.cn

\author{
Hong-hui Zhu, ${ }^{1}$ Jun Guo, ${ }^{1}$ Oing Yao, ${ }^{2}$ Song-zhen Yang, ${ }^{1}$ \\ Ming-rong Deng, ${ }^{1}$ Le Thi Bich Phuong, ${ }^{3}$ Vo Thi Hanh ${ }^{3}$ \\ and Matthew J. Ryan ${ }^{4}$ \\ ${ }^{1}$ Guangdong Provincial Microbial Culture Collection and Application Key Laboratory, \\ Guangdong Institute of Microbiology, Guangzhou, Guangdong 510070, China \\ ${ }^{2}$ South China Agricultural University, Guangzhou, Guangdong 510642, China \\ ${ }^{3}$ Institute of Tropical Biology, Vietnamese Academy of Science and Technology, Ho Chi Minh City, \\ Vietnam \\ ${ }^{4} \mathrm{CABI}$ Bioscience UK Centre, Egham, Surrey, UK
}

Streptomyces species are abundant in terrestrial environments and are easily isolated on simple laboratory media. They have broad metabolic capabilities and can produce pigments and antibiotics; they have use in various applications, especially in the food and pharmaceutical industries. Strain GIMV4.0001 ${ }^{\mathrm{T}}$ was isolated from the forest at Do Xongpha, Vietnam, in September 2004. [The soil samples were inoculated into Gause's synthetic agar medium (Atlas, 1993) and incubated for 5-7 days at $\left.28{ }^{\circ} \mathrm{C}\right]$. The strain produced large quantities of violet-blue diffusible pigment on Gause's synthetic agar medium.

Abbreviations: DAP, diaminopimelic acid; ISP, International Streptomyces Project.

The GenBank/EMBL/DDBJ accession number for the 16S rRNA gene sequence of Streptomyces vietnamensis GIMV4.0001 ${ }^{\top}$ is DQ3 11081.
International Streptomyces Project (ISP) media were prepared according to the methods of Shirling \& Gottlieb (1966). Morphological and physiological characteristics were determined as recommended by Williams et al. (1989). Morphological observations of spores and mycelia were conducted via light microscopy (Leica DM RAR) and scanning electron microscopy (Phillip FEI-XL30). Physiological tests were carried out at $28{ }^{\circ} \mathrm{C}$ (unless otherwise indicated). All carbon sources for carbon-utilization tests were filter-sterilized. Melibiose, glucose, sorbinose, sucrose, D-fructose, xylose, D-galactose, rhamnose, arabinose and D-mannitol were tested as sole carbon source at concentrations of $0.1 \%(\mathrm{w} / \mathrm{v})$. Colour determination was referenced against Kornerup \& Wanscher (1978).

Analysis of the isomer of diaminopimelic acid (DAP) and the whole-cell sugar composition followed the procedure 
Table 1. Cultural characteristics of strain GIMV4.0001 ${ }^{\top}$ on various media

ISP media (Shirling \& Gottlieb, 1966) are described in the text. Diffusible pigment was observed on most of the media listed. Colour comparisons were made against Kornerup \& Wanscher (1978).

\begin{tabular}{|c|c|c|c|c|c|c|}
\hline Characteristic & ISP2 & ISP3 & ISP4 & ISP5 & Czapek agar & $\begin{array}{c}\text { Gause's synthetic } \\
\text { agar }\end{array}$ \\
\hline Growth & Good & Good & Moderate & Moderate & Poor & Good \\
\hline \multicolumn{7}{|l|}{ Colour of: } \\
\hline Aerial mycelium & White & White & White & White & White & White \\
\hline Substrate mycelium & Reddish brown & Reddish brown & Reddish brown & Reddish brown & Greyish orange & Reddish brown \\
\hline
\end{tabular}

described by Hasegawa et al. (1983) with the exception that dried cells were used instead of colonies from agar plates. Fatty acid methyl esters were prepared by using the trimethyl sulfonium hydroxide method (Butte, 1983). The base composition of the genomic DNA of strain GIMV4.0001 ${ }^{\mathrm{T}}$ was determined in $0.1 \times$ SSC following the method of Mandel \& Marmur (1968). Genomic DNA was extracted (Cui et al., 2001) and the 16S rRNA gene sequence was amplified by PCR by using universal bacterial $16 \mathrm{~S}$ rRNA gene primers. The forward primer F27 (5'AGAGTTTGATCCTGGCTCAG-3') and reverse primer 1522R (5'-AAGGAGGTGATCCAGCCGCA-3') were adapted from primers $\mathrm{pA}$ and $\mathrm{pH}$ of Edwards et al. (1989). The 16S rRNA gene was sequenced using an automated capillary DNA sequencing system (ABI 3730) and a Bigdye Terminator cycle sequencing kit. DNA relatedness studies were conducted by using the fluorometric microdilution plate method (Ezaki et al., 1988; Sawabe et al., 1998).

Strain GIMV4.0001 ${ }^{\mathrm{T}}$ grew well on yeast extract/malt extract agar (ISP2), oatmeal agar (ISP3) and Gause's synthetic agar. It exhibited moderate growth on inorganic salts/starch agar (ISP4) and glycerol-asparagine agar (ISP5), but poor growth on Czapek agar media (Atlas, 1993). Diffusible pigments of different colours were produced on the various test media (Table 1). The colour range was from bluish violet (18C8) to violet-blue (19C8).

Morphological features were observed on ISP2, ISP3, ISP4 and ISP5. Cultures were incubated for 2 weeks at $28{ }^{\circ} \mathrm{C}$. Strain GIMV4.0001 ${ }^{\mathrm{T}}$ showed characteristics typical of the genus Streptomyces. Microscopical studies revealed a branched mycelium without verticils. The aerial mycelium produced flexuous (rectiflexibiles) spore chains. Spores were cylindrical and smooth (Fig. 1).

Chemotaxonomic tests showed that the cell wall contained LL-DAP, indicating that it was of cell-wall type I (Lechevalier \& Lechevalier, 1970). Whole-cell hydrolysates contained mainly mannose and small quantities of ribose and galactose. Fatty acid analysis showed that strain GIMV4.0001 ${ }^{\mathrm{T}}$ contained straight-chain, and iso- and anteiso-branched components and a high proportion of unsaturated components: iso- $\mathrm{C}_{14: 0}(6.995 \%)$, anteiso$\mathrm{C}_{16: 0}(20.1 \%), \mathrm{C}_{18: 0} \quad(5.8 \%), \mathrm{C}_{16: 1} \quad(17.8 \%), \mathrm{C}_{18: 1}$ $(33.5 \%)$ and $\mathrm{C}_{18: 2}(15.8 \%)$. The $\mathrm{G}+\mathrm{C}$ content of the genomic DNA was $73.9 \mathrm{~mol} \%$. Melanin was produced on tyrosine agar (ISP7).

A 1419-bp 16S rRNA gene sequence was determined for strain GIMV4.0001 $1^{\mathrm{T}}$. A BLAST search (Altschul et al., 1997) of the GenBank database using this sequence showed its similarity to that of many species of the genus Streptomyces. The 16S rRNA gene sequence of strain GIMV4.0001 ${ }^{\mathrm{T}}$ showed levels of similarity of $99.4 \%$ (over 1410 bases) to that of Streptomyces bikiniensis ATCC $11062^{\mathrm{T}}$ (GenBank accession no. X79851), $98.9 \%$ (over 1404 bases) to that of Streptomyces showdoensis ATCC $15105^{\mathrm{T}}$ (GenBank accession no. AY999741), 99.1\% (over 1406 bases) to that of Streptomyces viridobrunneus ATCC $43698^{\mathrm{T}}$ (GenBank accession no. AJ781372) and $<98 \%$ to that of other Streptomyces species.

A phylogenetic tree based on $16 \mathrm{~S}$ rRNA gene sequences of members of the genus Streptomyces was constructed

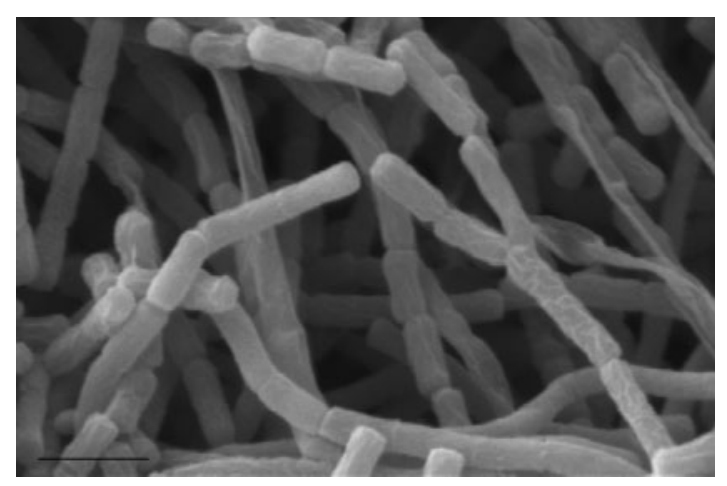

Fig. 1. Scanning electron micrograph of cells of strain GIMV4. $0001^{\top}$ grown on inorganic salts/starch agar (ISP4) at $28{ }^{\circ} \mathrm{C}$ for 14 days. Flexuous spore chains (rectiflexibiles) of cylindrical spores are evident. Bar, $2 \mu \mathrm{m}$. 


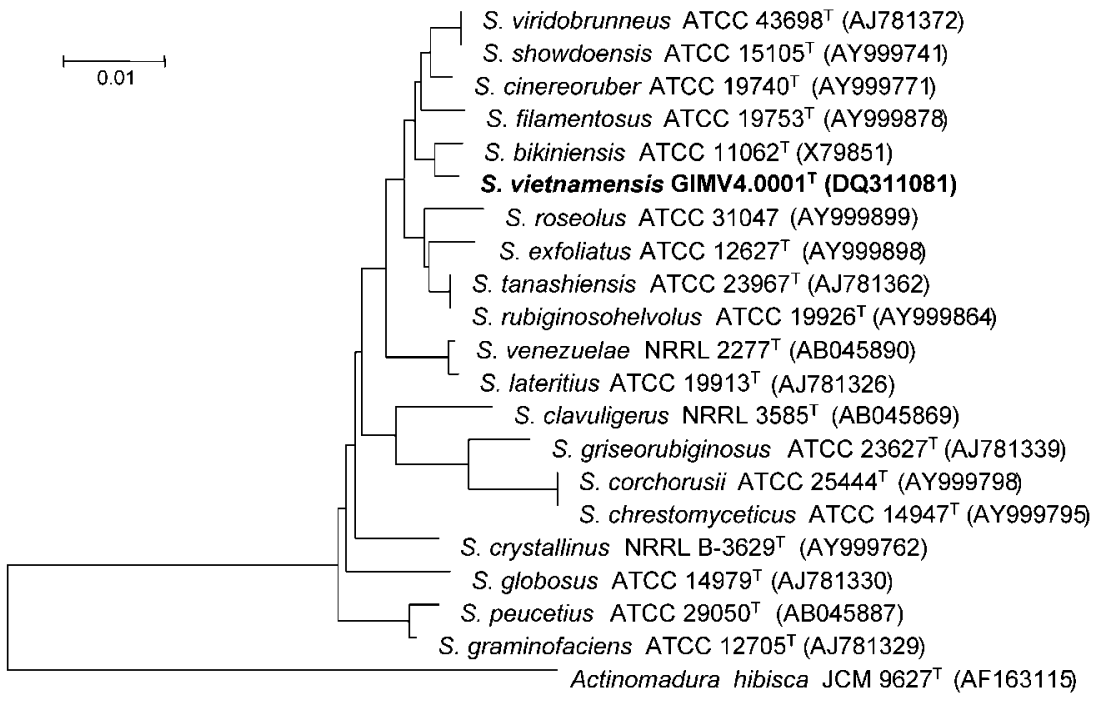

Fig. 2. Unrooted phylogenetic tree based on 16S rRNA gene sequences, showing the relationship between strain GIMV4.0001 ${ }^{\top}$ and Streptomyces species belonging to the major, minor and single member clusters defined by Williams et al. (1983). The $16 \mathrm{~S}$ rRNA gene sequence of Actinomadura hibisca JCM $9627^{\top}$ was used as an outgroup. GenBank sequence accession numbers are given in parentheses. The tree was generated by using the neighbour-joining method. Bar, 0.01 substitutions per nucleotide position. according to the neighbour-joining method of Saitou \& Nei (1987) with CLUSTAL W (version 1.81) and MEGA (version 3.1; Kumar et al., 2001) (Fig. 2). For the neighbour-joining analysis, a distance matrix was calculated according to Kimura's two-parameter correction model. This tree shows the close phylogenetic association of strain GIMV4.0001 ${ }^{\mathrm{T}}$ with certain other Streptomyces species.

The morphological and physiological characteristics of strain GIMV4.0001 ${ }^{\mathrm{T}}$, for example its cell-wall type, wholecell sugar pattern and fatty acid profile, were also consistent with those of members of the genus Streptomyces.

Strain GIMV4.0001 ${ }^{\mathrm{T}}$ produced reddish-brown substrate mycelium and grey spore mass, and developed cylindrical spores in flexuous chains. Melanin was produced. Bluishviolet or violet-blue diffusible pigments were produced. The pigment was $\mathrm{pH}$-sensitive, and was stable at high temperature and under UV light. Comparison of the cultural characteristics of strain GIMV4.0001 ${ }^{\mathrm{T}}$ and its closest phylogenetic neighbours (Table 2), however, revealed significant differences from those Streptomyces species showing $>99 \% 16 \mathrm{~S}$ rRNA gene sequence similarity.
S. bikiniensis differed from strain GIMV4.0001 ${ }^{\mathrm{T}}$ in that it did not produce a diffusible pigment on ISP media; $S$. showdoensis did not produce diffusible pigment on ISP media and $S$. viridobrunneus produced a green pigment. Despite the high 16S rRNA gene sequence similarity between strain GIMV4.0001 ${ }^{\mathrm{T}}$ and S. bikiniensis, they could be differentiated based on morphological and cultural characteristics (Table 2), carbon-utilization patterns, fatty acid methyl esters and antibiotic resistance properties (Table 3), indicating that strain GIMV4.0001 ${ }^{\mathrm{T}}$ does not belong to $S$. bikiniensis. DNA-DNA hybridization studies confirmed that strain GIMV4.0001 ${ }^{\mathrm{T}}$ is unique. The level of DNA-DNA relatedness between strain GIMV4.0001 ${ }^{\mathrm{T}}$ and S. bikiniensis ATCC $11062^{\mathrm{T}}$ was $50.3 \%$.

Other Streptomyces species that showed $>98 \% 16 \mathrm{~S}$ rRNA gene sequence similarity to strain GIMV4.0001 ${ }^{\mathrm{T}}$ revealed significant differences when grown on ISP media. For example, Streptomyces tanashiensis, Streptomyces cinereoruber, Streptomyces filamentosus and Streptomyces venezuelae differed from strain GIMV4.0001 ${ }^{\mathrm{T}}$ in that they did not produce pigments (Shirling \& Gottlieb, 1968a, b, 1969); Streptomyces exfoliatus differed in producing pink aerial mycelium but no substrate mycelial pigment (Shirling \&

Table 2. Cultural characteristics of strain GIMV4.0001 ${ }^{\top}$ and its phylogenetic neighbours

Data for reference species were taken from Shirling \& Gottlieb (1968b, 1972), Preobrazhenskaya et al. (1983) and Williams et al. (1983).

\begin{tabular}{|lcccc|}
\hline Characteristic & Strain GIMV4.0001 & S. bikiniensis & S. showdoensis & S. viridobrunneus \\
\hline Colony colour on ISP2 & Grey-white & Grey & Grey-white & Grey \\
Spore shape & Cylindrical & Oval & Ellipsoid or column & Oval or long round \\
Spore chain morphology & Straight or flexuous & Straight to flexuous & Long straight or flexuous & Straight or flexuous \\
Spore surface & Smooth & Smooth & Smooth & Smooth \\
$\begin{array}{l}\text { Production of diffusible } \\
\text { pigment }\end{array}$ & Violet-blue & - & - & Green \\
& & & & \\
\hline
\end{tabular}


Table 3. Phenotypic properties of strain GIMV4.0001 ${ }^{\top}$ and S. bikiniensis ATCC $11062^{\top}$

\begin{tabular}{|c|c|c|}
\hline Characteristic & Strain GIMV4.0001 ${ }^{\mathrm{T}}$ & S. bikiniensis ATCC $11062^{\mathrm{T}}$ \\
\hline Milk coagulation & + & + \\
\hline Milk peptonization & + & + \\
\hline $\mathrm{H}_{2} \mathrm{~S}$ production & + & + \\
\hline Melanin & + & + \\
\hline \multicolumn{3}{|l|}{ Growth on sole carbon source: } \\
\hline D-Fructose & + & + \\
\hline Sucrose & + & - \\
\hline D-Mannitol & - & + \\
\hline Rhamnose & - & Weak \\
\hline Xylose & + & Weak \\
\hline Raffinose & Weak & - \\
\hline Fatty acids & $\begin{array}{l}\text { iso- } \mathrm{C}_{14: 0}(6.995 \%) \text {, anteiso- } \mathrm{C}_{16: 0}(20.1 \%), \mathrm{C}_{18: 0} \\
(5.8 \%), \mathrm{C}_{16: 1}(17.8 \%), \mathrm{C}_{18: 1}(33.5 \%), \mathrm{C}_{18: 2} \\
(15.8 \%)\end{array}$ & $\begin{array}{c}\mathrm{C}_{12: 0}(6.209 \%), \mathrm{C}_{14: 0}(5.432 \%), \mathrm{C}_{15: 0}(4.649 \%) \\
\mathrm{C}_{16: 0}(59.832 \%), \mathrm{C}_{18: 0}(23.877 \%)\end{array}$ \\
\hline Antibiotic resistance & $\begin{array}{l}\text { No antibiosis exhibited against } E \text {. coli ATCC } 25922 \text {, } \\
\text { Pseudomonas aeruginosa ATCC } 6538 \text {, B. subtilis } \\
\text { ATCC } 6633 \text {, C. albicans ATCC 10231, Penicillium } \\
\text { citrinum AS3.2788 }\end{array}$ & $\begin{array}{l}\text { Antibiosis is exhibited against } E \text {. coli ATCC } 25922 \text {, } \\
\text { Pseudomonas aeruginosa ATCC } 6538, \text { B. subtilis } \\
\text { ATCC 6633, C. albicans ATCC 10231, Penicillium } \\
\text { citrinum AS3.2788 }\end{array}$ \\
\hline
\end{tabular}

Gottlieb, 1968a); Streptomyces rubiginosohelvolus produced either a light-yellow diffusible pigment and light-yellow aerial mycelium or no pigment at all (Shirling \& Gottlieb, 1968b); Streptomyces crystallinus produced a light-brown or dark-brown diffusible pigment (Williams et al., 1989).

These results support the classification of strain GIMV4.0001 ${ }^{\mathrm{T}}$ as representing a novel species of the genus Streptomyces, for which we propose the name Streptomyces vietnamensis sp. nov. Additional data from the phenotypic characterization of strain GIMV4.0001 ${ }^{\mathrm{T}}$ are presented below.

\section{Description of Streptomyces vietnamensis sp. nov.}

Streptomyces vietnamensis (vi.et.nam.en'sis. N.L. masc. adj. vietnamensis pertaining to Vietnam, the geographical location from where the type strain was isolated).

Aerobic, Gram-positive, catalase-positive and forms a white aerial mycelium and a reddish-brown substrate mycelium. Verticils are not present. The mycelium does not fragment. Straight to flexuous chains of cylindrical spores are produced. Diffusible pigments are produced on ISP2, ISP3, ISP4 and ISP5 media and on Gause's synthetic agar, but not on Czapek solution agar. Melanin is produced on ISP7. Although growth on ISP4 is initially slow, very good growth with profuse sporulation is observed on this medium after 14 days. Very good growth occurs on ISP2, Gause's synthetic agar and ISP3. Moderate growth is observed on ISP5 but only poor growth on Czapek agar. The substrate mycelium is reddish brown on
ISP2, ISP5, Gause's synthetic agar, ISP4 and ISP3, but greyish orange on Czapek medium. Cell wall contains LLDAP (cell-wall type I). Whole-cell sugar pattern contains diagnostic sugars: mannose, small quantities of ribose and galactose. No antibiosis is exhibited against Escherichia coli ATCC 25922, Pseudomonas aeruginosa ATCC 6538, Bacillus subtilis ATCC 6633, Candida albicans ATCC 10231 or Penicillium citrinum AS3.2788. Utilizes melibiose, glucose, sorbinose, sucrose, D-fructose, xylose, D-galactose, rhamnose and arabinose. Positive for production of $\mathrm{H}_{2} \mathrm{~S}$, but pectin is not hydrolysed. The DNA $\mathrm{G}+\mathrm{C}$ content of the type strain is $73.9 \mathrm{~mol} \%$.

The type strain, GIMV4.0001 ${ }^{\mathrm{T}}$ (=CCTCC M 205143 ${ }^{\mathrm{T}}=$ IAM $15340^{\mathrm{T}}$ ), was isolated from a forest soil sample in Vietnam

\section{Acknowledgements}

This research was supported by the Guangdong Ministry of Science and Technology, PR China (project no. 2004B50201011). We thank Dr Tai-hui Li (Guangdong Institute of Microbiology) for collecting soil in Vietnam and Dr David P. Labeda (National Center for Agricultural Utilization Research) for his constructive suggestion and grammatical correction of the manuscript.

\section{References}

Altschul, S. F., Madden, T. L., Schaffer, A. A., Zhang, J., Zhang, Z., Miller, W. \& Lipman, D. J. (1997). Gapped BLAST and PSI-BLAST: a new generation of protein database search programs. Nucleic Acids Res 25, 3389-3402. 
Atlas, R. M. (1993). Handbook of Microbiological Media. Edited by L. C. Parks. Boca Raton, FL: CRC Press.

Butte, W. (1983). Rapid method for the determination of fatty acid profiles from fats and oils using trimethylsulphonium hydroxide for transesterification. J Chromatogr 261, 142-145.

Cui, X. L., Mao, P. H., Zeng, M., Li, W. J., Zhang, L. P., Xu, L. H. \& Jiang, C. L. (2001). Streptimonospora salina gen. nov., sp. nov., a new member of the family Nocardiopsaceae. Int J Syst Evol Microbiol 51, 357-363.

Edwards, U., Rogall, T., Blocker, H., Emde, M. \& Bottger, E. C. (1989). Isolation and direct complete nucleotide determination of entire genes, characterization of gene coding for $16 \mathrm{~S}$ ribosomal RNA. Nucleic Acids Res 17, 7843-7853.

Ezaki, T., Hashimoto, Y., Takeuchi, N., Yamamoto, H., Liu, S.-L., Miura, H., Matsui, K. \& Yabuuchi, E. (1988). Simple genetic method to identify viridans group streptococci by colorimetric dot hybridization and fluorometric hybridization in microdilution wells. J Clin Microbiol 26, 1708-1713.

Hasegawa, T., Takizawa, M. \& Tanida, S. (1983). A rapid analysis for chemical grouping of aerobic actinomycetes. J Gen Appl Microbiol 29, 319-322.

Kornerup, A. \& Wanscher, J. H. (1978). Methuen Handbook of Colour. London: Eyre Methuen.

Kumar, S., Tamura, K., Jakobsen, I. B. \& Nei, M. (2001). MEGA2: Molecular Evolutionary Genetics Analysis software. Tempe, AZ: Arizona State University. http://www.megasoftware.net

Lechevalier, M. P. \& Lechevalier, H. A. (1970). A critical evaluation of the genera of aerobic actinomycetes. In The Actinomycetales, pp. 393-405. Edited by H. Prauser. Jena: Gustav Fischer.

Mandel, M. \& Marmur, J. (1968). Use of ultraviolet absorbancetemperature profile for determining the guanine plus cytosine content of DNA. Methods Enzymol 12B, 195-206.
Preobrazhenskaya, T. P., Sveshnikova, M. A., Terekhova, L. P. \& Maximova, T. S. (1983). A Guide for the Determination of Actinomycetes. Genera Streptomyces, Streptoverticillium, and Chainia. Moscow: Nauka.

Saitou, N. \& Nei, M. (1987). The neighbor-joining method: a new method for reconstructing phylogenetic trees. Mol Biol Evol 4, 406-425.

Sawabe, T., Makino, H., Tatsumi, M., Nakano, K., Tajima, K., lqbal, M. M., Yumoto, L., Ezura, Y. \& Christen, R. (1998). Pseudomoalteromonas bacteriolytica sp. nov., a marine bacterium that is the causative agent of red spot disease of Laminaria japonica. Int $J$ Syst Bacteriol 48, 769-774.

Shirling, E. B. \& Gottlieb, D. (1966). Methods for characterization of Streptomyces species. Int J Syst Bacteriol 16, 313-340.

Shirling, E. B. \& Gottlieb, D. (1968a). Cooperative description of type cultures of Streptomyces. II. Species descriptions from first study. Int $J$ Syst Bacteriol 18, 69-189.

Shirling, E. B. \& Gottlieb, D. (1968b). Cooperative description of type cultures of Streptomyces. III. Additional species descriptions from first and second studies. Int J Syst Bacteriol 18, 279-392.

Shirling, E. B. \& Gottlieb, D. (1969). Cooperative description of type cultures of Streptomyces. IV. Species descriptions from the second, third and fourth studies. Int J Syst Bacteriol 19, 391-512.

Shirling, E. B. \& Gottlieb, D. (1972). Cooperative description of type strains of Streptomyces. V. Additional descriptions. Int J Syst Bacteriol 22, 265-394.

Williams, S. T., Goodfellow, M., Alderson, G., Wellington, E. M. H., Sneath, P. H. A. \& Sackin, M. J. (1983). Numerical classification of Streptomyces and related genera. J Gen Microbiol 129, 1743-1813.

Williams, S. T., Goodfellow, M. \& Alderson, G. (1989). Genus Streptomyces Waksman and Henrici 1943, 339 ${ }^{\mathrm{AL}}$. In Bergey's Manual of Systematic Bacteriology, vol. 4, pp. 2452-2492. Edited by S. T. Williams, M. E. Sharpe \& J. G. Holt. Baltimore: Williams \& Wilkins. 